Akuntabilitas: Jurnal Ilmu Akuntansi

Volume 10 (I), April 2017

P-ISSN: 1979-858X; E-ISSN: 246I-II 90

Page 63 - 78

\title{
Etika Perataan Laba dari Perspektif Akuntansi Syariah
}

\author{
Suwandi \\ Universitas Muhammadiyah Gresik \\ suwandi@umg.ac.id
}

\begin{abstract}
This study aims to find out the ethics of income smoothing seen from the perspective of Islamic religion because the action of income smoothing (smoothing earnings) is an action that can mislead the users of financial statements by presenting information that is not accurate, and sometimes even the cause of illegal acts, accountants educators, managers, and Ustadz believes it is an act that is prohibited by religion because the nature of the work it does is a mandate, whether it is worldly from its superior or business owner, or worldly from Allah SWT who will be held accountable for the work he does. Implementation of honest and trustworthy in work among others is to not take something that is not his right. The reason of the selection of informants is because all three have a relationship to the practice of Income Statement and all informants argue the same. The performance of unstable financial statements or decreased financial performance is less good, it tends to trigger the behavior of managers to perform unethical actions, so to give the impression of good company performance needs to be done income smoothing, income smoothing can be done by manipulating variables -variables (accounting) pseudo or by conducting real transactions, or can also be done by choosing an accounting method in accordance with the wishes of management.
\end{abstract}

Keywords: ethics, income smoothing, Islamic accounting

\begin{abstract}
Abstrak
Penelitian ini bertujuan untuk mengetahui tentang etika perataan laba dilihat dari perpektif agama isalam karena tindakan income smoothing (perataan laba) merupakan tindakan yang dapat menyesatkan pemakai laporan keuangan dengan menyajikan informasi yang tidak akurat, dan bahkan kadang merupakan penyebab terjadinya tindakan illegal, berbagai profesi seperti akuntan pendidik, manajer, dan Ulama berpendapat itu merupakan perbuatan yang dilarang oleh agama karena hakekatnya pekerjaan yang dilakukannya tersebut merupakan amanah, baik secara duniawi dari atasannya atau pemilik usaha, maupun secara duniawi dari Allah SWT yang akan dimintai pertanggung jawaban atas pekerjaan yang dilakukannya. Implementasi jujur dan amanah dalam bekerja diantaranya adalah dengan tidak mengambil sesuatu yang bukan menjadi haknya. Alasan dari pemilihan informan tersebut karena ketiganya mempunyai hubungan atas praktik Perataan Laba dan semua informan berpendapat yang sama. Kinerja laporan keuangan yang tidak stabil atau mengalami penurunan kinerja keuangan yang kurang baik, cenderung itu sebagai pemicu perilaku manajer untuk malakukan tindakan-tindakan yang tidak etis, sehingga untuk memberikan kesan kinerja perusahaan yang baik perlu dilakukan perataan laba, perataan laba dapat dilakukan dengan memanipulasi variabel-variabel (akuntansi) semu atau dengan melakukan transaksi-transaksi rill, atau bisa juga dilakukan dengan memilih metode akuntansi yang sesuai dengan keinginan manajemen.
\end{abstract}

Kata kunci: etika, perataan laba, akuntansi syariah

Diterima: 20 Januari 2017; Revisi: 3 Maret 2017; Disetujui: 30 Maret 2017 


\section{PENDAHULUAN}

Income smoothing (perataan laba) adalah suatu perilaku yang rasional yang didasarkan pada asumsi dalam positive accounting theory, dimana manajemen suatu perusahaan melakukan kebijakan tertentu untuk memaksimumkan kepentingannya. Penelitian ini bertujuan untuk mengkaji implikasi praktik income smoothing pada laporan keuangan perusahaan serta untuk melihat kepatutannya dalam sistem ekonomi Islam. Untuk mendapatkan jawabannya, kajian ini menggunakan metode analisis isi (content analysis) dan deskriptif analisis (descriptive analysis). Hasil kajian menunjukkan bahwa dari sudut pandang etika secara umum ada dua pendapat yang bertolak belakang menganggap wajar dan menganggap tidak etis. Akan tetapi pendapat yang kedua (menganggap tidak etis) lebih kuat, karena jumlah laba yang dihasilkan perusahaan tidak sesuai dengan keadaa sesunggunya dalam waktu periode tersebut, hal itu akan mengelabui stakeholders terhadap kondisi keuangan perusahaan secara riil.

Semakin berkembangnya kebutuhan informasi oleh pemakai laporan keuangan, maka dalam akuntansi terdapat dua metode pencatatan transaksi yang berkaitan dengan arus kas masuk dan kas keluar. Kedua metode tersebut adalah metode pencatatan berbasis kas (cash basis) dan metode pencatatan berbasis akrual (accrual basis). Keduanya memiliki dasar yang mengasumsikan metode pencatatan mana yang akan digunakan oleh entitas atau perusahaan dalam proses akuntansinya. Asas akrual sebagai konsep dasar akuntansi lebih diterima dan dijadikan kebijakan akuntansi entitas secara umum. Hal ini karena konsepnya yang lebih mencerminkan laporan sumber daya ekonomi perusahaan baik yang telah dimiliki atau yang berpotensi menjadi sumber daya ekonomi entitas. Sebab pada dasarnya akuntansi hanya menyajikan informasi keuangan masa lampau (historical cost). Hal ini menjadi kritik tersendiri bagi akuntansi, di mana sulit melihat prediksi masa depan perusahaan hanya dengan mengandalkan laporan keuangan yang berbasis informasi masa lampau (historical cost) tersebut.

Menurut Adnan (2005), aspek pengakuan memiliki peranan yang sangat penting sebagai dasar pengakuan prinsip yang mengatur kapan dicatatnya transaksi pendapatan, beban, laba, dan rugi. Konsep pengakuan akan berpengaruh banyak dalam menentukan aktiva, pasiva, dan laba rugi operasi perusahaan. Berbeda dengan pernyataan para ahli akuntansi Islam justru menyatakan hal yang bertentangan mengenai pencatatan transaksi akuntansi berbasis akrual. Beberapa ahli akuntansi Islam menentang basis akrual dengan 
menggunakan dalil QS Lukman ayat 34 yang menyatakan bahwa apa yang terjadi esok dan mendatang adalah ghoib. Sehingga tidak boleh pendapatan belum pasti dicatat sebagai penghasilan. Dengan diterapkannya basis akrual dalam akuntansi Islam, maka akan terjadi pendapatan perseroan lebih besar tetapi bagi hasil yang diperoleh kecil. Menurut Rais (2002), apabila surat Al-Baqarah ayat 282 dikaitkan dengan surat AlLukman ayat 34, maka akan ada indikasi bahwa basis akrual (khususnya pendapatan) tidak diperkenankan. Untuk memperkuat hal tersebut, sebagian ulama menyatakan bahwa peritah QS Al-Baqarah ayat 282 hanya sebatas mencatat transaksi bukan mengakui perolehannya. Pengakuan perolehan, baru dilakukan pada saat diterimanya dana (kas).

Seiring dengan berkembangnya bisnis yang semakin kompleks, penerapan akuntansi berbasis akrual membawa beberapa kelemahan. Konsep akrual ini dapat mengaburkan laporan keuangan yang bertujuan memberikan informasi tentang aliran kas dan mengaburkan kemampuan perusahaan dalam menghasilkan kas. Kekaburan informasi ini rentan terhadap tindakan manipulatif. Pengaburan informasi inilah yang memberikan peluang bagi manajer untuk melakukan Pearataan Laba (Income Smoothing).

\section{KAJIAN PUSTAKA}

Menurut Schipper (1989) menyatakan bahwa Pearataan Laba merupakan suatu intervensi dengan tujuan tertentu dalam proses pelaporan keuangan eksternal dengan maksud mendapatkan keuntungan pribadi. Umumnya Pearataan Laba terjadi ketika manajer menggunakan judgement dalam laporan keuangan dan penyusunan transaksi untuk mengubah laporan keuangan, sehingga dapat menyesatkan stakeholders tentang kinerja ekonomi perusahaan atau untuk mempengaruhi hasil yang berhubungan dengan kontrak yang tergantung pada angka akuntansi.

Beberapa motivasi terjadinya Pearataan Laba menurut Scott (2000:302) dalam Rahmawati dkk. (2006) yaitu adanya Bonus Purposes, Political Motivation, Taxation Motivation, Pergantian CEO, Initial Public Offering (IPO), dan pentingnya memberi informasi kepada Investor. Hal tersebut dapat menjadi salah satu diantara motivasi manajemen melakukan Pearataan Laba atas dasar kepentingan pribadi maupun kepentingan perusahaan. Strategi yang dapat diimplementasikan oleh manajer dalam 
Pearataan Laba antara lain adalah melakukan pilihan metode akuntansi serta melakukan estimasi tertentu sebagai kebijakan akuntansi.

Fischer dkk. (1995), Arlene (2005) menyebutkan bahwa banyak manajer yang menganggap Income Smoothing sebagai tindakan yang wajar dan etis serta merupakan alat sah manajer dalam melaksanakan tanggungjawabnya untuk mendapatkan return perusahaan. Menurut Merchant dkk. (1994), Pearataan Laba yang banyak dilakukan selama ini dianggap legal, artinya tidak bertentangan dengan prinsip-prinsip akuntansi yang berterima umum. Menurutnya, ethical judgement terhadap Income Smoothing cenderung berbeda antara kelompok individu. Perbedaan tersebut dipengaruhi oleh karakter individu seseorang dan karakter lingkungan seseorang. Perbedaan penilaian tentang praktik Perataan Laba semakin menegaskan bahwa ada faktor-faktor yang secara tidak sengaja dan tidak diketahui menstimulus perilaku mereka terhadap isu-isu etika.

Menurut Dimastidano (2007:2), Perataan Laba merupakan suatu tindakan yang tidak bermoral, walaupun Pearataan Laba dibuat berdasarkan Standar Akuntansi Keuangan yang berlaku, tetapi tidak berarti Perataan Laba merupakan tindakan cerdas untuk mengesahkan penipuan. Hal tersebut menunjukkan adanya perbedaan presepsi antar individu mengenai perilaku Perataan Laba.

Beberapa penelitian telah membuktikan adanya praktik Perataan Laba oleh para manajer. Dalam penelitiannya, Riduwan (2010) menyebutkan bahwa beberapa penelitian seperti: Neil, et al., 1995; DuCharme, et al., 2004; Ronen, et al., 2006; Herawati dan Baridwan, 2007; mengungkapkan bahwa sebagian besar Perataan Laba yang dilakukan oleh manajer adalah melalui strategi pemilihan metode akuntansi dan penentuan estimasi akuntansi, dan hanya sebagian kecil yang dilakukan melalui transaksi rill yang sah maupun transaksi fiktif. Namun, penelitian tersebut hanya mencoba untuk mengungkapkan ada atau tidaknya praktik Perataan Laba yang dilakukan oleh manajer, strategi yang digunakan, serta motivasi dan kepentingannya. Oleh karena itu, melalui pendekatan kualitatif, penelitian ini bermaksud untuk menggali informasi lebih lanjut tentang pendapat, sikap, maupun tanggapan para akuntan, investor, dan ulama' mengenai etika Perataan Laba yang dilakukan oleh manajer, yang secara tidak langsung merasakan dampak dari Perataan Laba tersebut 
Tindakan perataan laba yang dilakukan manajemen dapat dilihat dari dua cara. Pertama, tindakan perataan laba yang dipandang sebagai perilaku oportunistik manajemen untuk memaksimalkan utilitasnya dalam menghadapi kontrak kompensasi dan hutang Bila ditinjau dari sudut pandang etika, earnings management, dimana didalamnya termasuk tindakan income smoothing (perataan laba) merupakan tindakan yang dapat menyesatkan pemakai laporan keuangan dengan menyajikan informasi yang tidak akurat, dan bahkan kadang merupakan penyebab terjadinya tindakan illegal, misalnya penyajian laporan keuangan yang terdistorsi atau tidak sesuai dengan sebenarnya. Berdasarkan uraian tersebut peneliti merumuskan bagaimana etika perataan laba (income Smothing) yang dilakukan manajemen dalam menjalankan usaha dari Perspektif Agama Islam.

\section{METODE}

Penelitian ini berorientasi pada upaya untuk mengetahui, memahami, serta memaknai suatu konteks etika Perataan Laba dilihat perspektif agama Islam. Untuk mencapai pemahaman yang mendalam, penelitian ini menggunakan jenis data kualitatif. Jenis penelitian ini bersifat deskriptif dan cenderung menggunakan analisis. Selain itu, penelitian kualitatif jauh lebih subyektif daripada penelitian kuantitatif. Hal tersebut yang nantinya akan membantu peneliti dalam mengkaji lebih dalam mengenai etika Perataan Laba perspektif agama Islam dari informan.

Penelitian ini berdasar pada adanya studi kasus mengenai praktik Perataan Laba pada instansi atau perusahaan. Studi kasus adalah salah satu metode penelitian ilmu-ilmu sosial (Yin, 2002). Secara umum, studi kasus merupakan strategi yang lebih cocok bila pokok pertanyaan suatu penelitian berkenaan dengan "how" atau "why", bila peneliti hanya memiliki sedikit peluang untuk mengontrol peristiwa-peristiwa yang akan diselidiki, dan bilamana fokus penelitiannya terletak pada fenomena kontemporer (masa kini) di dalam konteks kehidupan nyata (Yin, 2002).

Penelitian ini dilakukan pada beberapa informan yang memahami Perataan Laba serta ajaran Islam. Informan yang dipilih sebagai nara sumber dalam penelitian ini adalah dari berbagai profesi yaitu: akuntan pendidik, manajer, dan Ulama'. Alasan dari pemilihan informan tersebut karena ketiganya mempunyai hubungan atas praktik Perataan Laba. Selain itu untuk presepsi etika sesuai dengan agama Islam dari masing- 
masing informan akan mempengaruhi hasil penelitian. penelitian kualitatif ada beberapa metode yang dapat digunakan untuk pengumpulan data, antara lain: wawancara, observasi, dan dokumentasi. Pengambilan data dilakukan secara alamiah atau berdasarkan pada kondisi nyata (kondisi sesungguhnya). Peneliti memilih untuk mengumpulkan data dengan menggunakan metode wawancara mendalam. Peneliti membuat rancangan pertanyaan yang berkaitan dengan rumusan masalah dalam penelitian ini, akan tetapi wawancara dilakukan secara tidak terstruktur dan informal kepada informan agar jawaban yang diberikan lebih luas.

Desain penelitian yang terkategorikan sebagai studi kasus, ditentukan oleh unit analisisnya, Yin (2006). Dalam penyusunan penelitian ini, peneliti menggunakan unit analisis sikap yang mencakup etika dalam Islam. Penentuan unit analisis ini didasarkan pada beberapa sikap etis yang menentukan bagaimana tanggapan informan mengenai etika praktik Perataan Laba perspektif agama Islam, sikap etis tersebut antara lain: kejujuran, amanah, kemanfaatan, dan tidak melupakan akhirat. Teknik analisis data yang digunakan pada penelitian ini mengacu pada Sanders (1982).dalam membagi empat tahap analisis data dalam penelitian fenomenologi, yaitu:

I. Deskripsi fenomena. Tahap awal penelitian dilakukan dengan mendiskripsikan fenomena yang berhubungan dengan masalah etika Perataan Laba. Dilihat dari hasil penelitian terdahulu yang juga menyatakan adanya perbedaan persepsi mengenai Perataan Laba. Hal tersebut dibahas dalam latar belakang masalah penelitian. Dengan melihat fenomena tersebut, peneliti akan lebih mudah merumuskan masalah yang nantinya menjadi bahasan penelitian.

2. Identifikasi tema-tema. Tahapan kedua yakni mengidentifikasi tema-tema, tahap ini merupakan salah satu proses penelitian yang boleh dikatakan paling penting diantara proses lain. Tanpa identifikasi masalah, proses deskripsi masalah akan menjadi sia-sia. Suatu kegiatan yang dilakukan untuk menemukan informasi yang berkaitan dengan masalah yang akan diteliti.

3. Mengembangkan neotic/neeomatic correlates. Tahapan ketiga dari penelitian ini yakni dengan mengembangkan noetic/neeomatic. Noetic ini merupakan pengembangan pikiran dan intuisi dalam hubungannya dengan intelektual Illahi.

4. Abstraksi intisari atau universals dari neotic/neeomatic correlates. Setelah mengembangkan noetic, tahapan berikutnya yakni membuat abstraksi. Abstraksi ini 
merupakan penyajian singkat mengenai intisari dari noetic/neeomatic correlates. Abstraksi berfungsi untuk menjelaskan isi secara singkat kepada pembaca.

\section{HASIL DAN PEMBAHASAN}

Etika perspektif Islam adalah etika berdasarkan ketentuan peraturan yang telah dibuat oleh Allah SWT yang tertuang dalam ayat-ayat AI-Qur'an. Artinya, suatu perbuatan baik atau buruk itu tidak ditentukan oleh persepsi pandangan manusia semata, melainkan dari aturan-aturan dan norma-norma Agama yang telah diturunkan oleh Allah SWT dalam Al-Qur'an.

Terdapat beberapa pandangan dasar menurut para informan mengenai etika perataan laba. Salah satu pandangan adalah bahwa mekanisme perataan laba dikatakan tidak beretika karena praktik tersebut merupakan upaya manajer dalam rangka untuk meratakan laba yang mana hal tersebut tidak mencerminkan kondisi laporan keuangan yang sesungguhnya dan sebenarnya. Manajer mempunyai kewajiban dalam mengungkapkan atau menyampaikan laporan keuangan kepada pihak internal maupun eksternal perusahaan yang disampaikan dengan etika kejujuran, dapat dipercaya, dan tidak menyesatkan. Terkadang setiap individu mempunyai niat yang berbeda dalam melakukan suatu tindakan, pada hakikatnya segala setiap perbuatan dan tindakan harus didasari oleh niat dan iktikad baik.

Islam, mengajarkan kita mengikuti apa yang telah diperintahkan oleh Allah SWT dan meninggalkan apa yang menjadi larangan-Nya. Perbuatan mekanisme perataan laba merupakan tindakan yang dianggap tidak beretika karena tidak sesuai dengan perspektif Islam, Allah SWT memerintahkan umat-Nya untuk mencari laba dengan usaha yang baik, seperti yang terkandung dalam surat Al-Baqarah ayat 267 yang artinya:

"Hai orang-orang yang beriman, nafkahkanlah (di jalan Allah) sebagian dari hasil usahamu yang baik-baik dan sebagian dari apa yang Kami keluarkan dari bumi untuk kamu. Dan janganlah kamu memilih yang buruk-buruk lalu kamu menafkahkan daripadanya, padahal kamu sendiri tidak mau mengambilnya melainkan dengan memicingkan terhadapnya. Dan ketahuilah, bahwa Allah Maha Kaya lagi Maha Terpuji. Setan menjanjikan (menakut-nakuti) kamu dengan kemiskinan dan menyuruh kamu berbuat kejahatan (kikir), sedang Allah menjanjikan untukmu ampunan daripada-Nya dan karunia. Dan Allah Maha Luas (karunia-Nya) lagi Maha Mengetahui”. 
Pendapat tersebut menegaskan bahwa etika perspektif Islam dalam Ayat tersebut menggambarkan hubungan antara manusia dan sosial para kaum mukmin berlandaskan pada keadilan, kebaikan, tidak melakukan kedzaliman serta arogansi. Allah SWT melarang umat manusia untuk berbuat dzalim kepada siapapun dan menginjak hak orang lain. Tentunya etika Islam mendorong manusia berperilaku lebih dari tuntutan standar atau keadilan, dalam menyikapi permasalahan sosial yang terjadi sekarang ini umat manusia haruslah berbesar hati untuk saling memaafkan kesalahan Seperti terkandung dalam ayat berikut ini:

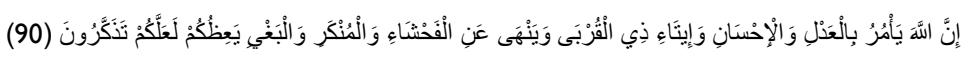

"Sesungguhnya Allah menyuruh kamu berlaku adil dan berbuat kebajikan, memberi kepada kamu kerabat, dan Allah melarang dari perbuatan keji, kemungkaran dan permusuhan. Dia memberi pengajaran kepadamu agar kamu dapat mengambil pelajaran”. (QS. An-Nahl : 90)

Sikap dan perilaku etis yang harus dimiliki oleh para manajer mengacu pada yang dicontohkan Rasulullah SAW. yakni meliputi sikap jujur (siddiq), dapat dipercaya (amanah), pandai (tabligh), dan mampu menghadapi persoalan apapun (fathonah). Dari berbagai analisis sikap dan perilaku tersebut, maka tindakan perataan laba tidak mengacu pada etika Islam. Sehingga dapat dikatakan bahwa perataan laba termasuk dalam tindakan yang tidak beretika yang tidak sesuai dengan syariat Islam. Sebagaimana dalam QS.Ali-Imran: I34 sebagai berikut:

"(yaitu) orang-orang yang menafkahkan (hartanya), baik di waktu lapang maupun sempit, dan orang-orang yang menahan amarahnya dan memaafkan (kesalahan) orang. Allah menyukai orang-orang yang berbuat kebajikan

Pada dasarnya etika atau moralitas itu manusiawi, artinya bersumber pada sistem nilai manusiawi (human value system). etika manusiawi, juga terdapat etika ilahi yang bersumber pada sistem nilai ketuhanan (divine value system) yang tertuang dalam firman Allah atau jajaran agama, Etika agama Islam pada dasarnya tidak pernah memisahkan nilai-nilai etis atau moral dari nilai-nilai hukum. Kedua diatur dalam Syari'ah Islam dan mengelompokkan keduanya dalam lima macam kategori : perintah keras (wajib); perintah lunak (sunnah); larangan keras (haram); perintah lunak (makrah), dan kebebasan (mubah). 
Al-Qur'an banyak sekali mengajarkan kita agar taqwa dalam setiap perkara dan pekerjaan. Jika Allah SWT ingin menyeru kepada orang-orang mukmin dengan nada panggilan seperti wahai orang-orang yang beriman, biasanya diikuti oleh ayat yang berorientasi pada kerja dengan muatan ketaqwaan. Di antaranya, keluarkanlah sebahagian dari apa yang telah kami anugerahkan kepadamu. Janganlah kamu ikuti/rusak sedekah-sedekah (yang telah kamu keluarkan) dengan olokan-olokan dan kata-kata yang menyakitkan.

Hai anak adam, sesungguhnya kami telah menurunkan kepadamu pakaian untuk menutupi auratmu dan pakaian indah untuk perhiasan. Dan pakaian takwa itulah yang paling baik, yang demikian itu adalah sebagaian dari tanda-tanda kekuasaan Allah, mudah-mudahan mereka selalu ingat (QS Al-A'raf)

Sikap ini muncul dari iman dan rasa takut individu terhadap Allah. Kesadaran ketuhanan dan spiritualitasnya mampu melahirkan sikap-sikap kerja positif. Kesadaran bahwa Allah melihat, mengontrol dalam kondisi apapun, serta akan menghisab seluruh amal perbuatannya secara adil, kemudian akan membalasnya dengan pahala atau siksaan di dunia, Aspek profesionalisme ini amat penting bagi seorang pekerja. Maksudnya adalah kemampuan untuk memahami dan melaksankan pekerjaan sesuai dengan prinsipnya (keahlian). Pekerja tidak cukup hanya dengan memegang teguh sifat-sifat amanah, kuat, berakhlaq dan bertakwa, namun dia harus pula mengerti dan menguasai benar pekerjaannnya. Jadi tanpa adanya profesionalisme atau keahlian, suatu usaha akan mengalami kerusakan dan kebangkrutan. Juga menyebabkan menurunnya kualitas dan kuantitas produksi, bahkan sampai pada kesemrawutan manajemen, serta kerusakan alat-alat produktivitas

Perataan laba merupakan salah satu upaya untuk memanipulasi laporan keuangan agar terlihat lebih stabil dan menarik dari tahun ke tahun yang disajikan untuk pihak eksternal. Ini merupakan upaya yang dilakukan perusahaan mempunyai kinerja laporan keuangan yang tidak stabil atau mengalami penurunan kinerja keuangan yang kurang baik, sehingga untuk memberikan kesan kinerja perusahaan yang baik perlu dilakukan perataan laba, perataan laba dapat dilakukan dengan memanipulasi variabel-variabel (akuntansi) semu atau dengan melakukan transaksi-transaksi rill, atau bisa juga dilakukan dengan memilih metode akuntansi yang sesuai dengan keinginan manajemen 
Pemicu Bonus plan seringkali menjadi alasan utama manajer melakukan perataan laba, faktor lain yang juga menjadi pemicu terjadinya perataan laba di perusahaan ada faktor kepentingan bagi pihak perusahaan. Kepentingan tersebut mendominasi niatnya, niat yang dimiliki biasanya dibalut oleh etika owner perusahaan. Apakah etika tersebut berbasis pada keimanan tertentu atau bersifat materi semata, Pemilihan metode akuntansi tentunya harus sesuai dengan kebutuhan manajemen dan kepentingan perusahaan. Metode akuntansi sangat beragam sehingga memudahkan prilaku pelaku yang menyusun dan membuat laporan keuangan untuk memilih mana metode yang tepat sesuai dengan tipe perusahaannya. Teknik tersebut sangat umum digunakan untuk melakukan pengelolaan laba misal memilih metode persediaan sudah barang tentu akan terjadi perubahan laba dalam laporan keuangan.

Menurut para informan mengenai etika perataan laba. Salah satu pandangan adalah bahwa perataan laba dikatakan tidak beretika karena praktik tersebut merupakan upaya manajer untuk meratakan laba yang sesungguhnya atau sebenarnya (riil) manajer mempunyai kewajiban dalam mengungkapkan laporan keuangan kepada pihak internal maupun eksternal perusahaan yang tidak menyesatkan, pada hakikatnya segala perbuatan harus didasari dengan niat dan iktikad baik. Karena pada hakekatnya pekerjaan yang dilakukannya tersebut merupakan amanah, baik secara duniawi dari atasannya atau pemilik usaha, maupun secara duniawi dari Allah SWT yang akan dimintai pertanggung jawaban atas pekerjaan yang dilakukannya. Implementasi jujur dan amanah dalam bekerja diantaranya adalah dengan tidak mengambil sesuatu yang bukan menjadi haknya, tidak curang, obyektif dalam menilai, dan sebagainya. Dalam sebuah hadits Rasulullah SAW bersabda:

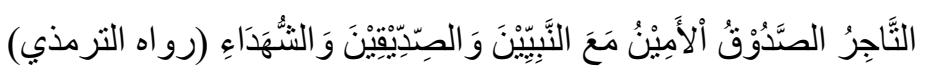

Seorang pebisnis yang jujur lagi dapat dipercaya, (kelak akan dikumpulkan) bersama para nabi, shiddiqin dan syuhada'. (HR. Turmudzi)

Bekerja jangan dusta, sesungguhnya dusta itu mengantarkan kepada perbuatan dosa yang menyebabkan masuk neraka. Dusta itu dibenci oleh Allah SWT dan manusia. jika dia menyampaikan berita, beritanya tidak tsiqah (terpercaya). Ketahuilah bahwa dusta ini juga mencakup keyakinan, perbuatan dan perkataan. Dusta dalam keyakinan maksudnya adalah perbuatan manusia yang dilakukan karena riya'(pamer) dan hanya mengharapkan pujian manusia semata. Seperti halnya firman Allah: 


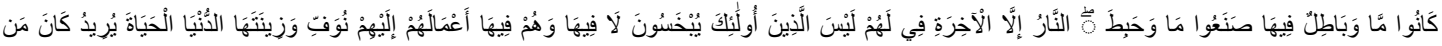

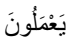

Barangsiapa yang menghendaki kehidupan dunia dan perhiasannya, niscaya Kami berikan kepada mereka balasan pekerjaan mereka di dunia dengan sempurna dan mereka di dunia itu tidak akan dirugikan. Itulah orang-orang yang tidak memperoleh di akhirat, kecuali neraka dan lenyaplah di akhirat itu apa yang telah mereka usahakan di dunia dan sia-sialah apa yang telah mereka kerjakan.[ Huud/II:I5-I6]

Perataan laba adalah merupakan upaya manajer dalam memberikan informasi kepada pihak internal atau eksternal akan kondisi perusahaan yang tidak sebenarnya pada periode tertentu dalam rangka untuk menstabilkan posisi laporan keuangan sehingga terkesan perusahaan akan memiliki kinerja yang secara terus menerus stabil. Dalam pandangan agama isalam ini bagian dari kecurangan informasi dan sikap menyianyiakan amanah pada sebagian para pimpinan yana pada saat ini sudah tidak menjadi rahasia umum. Kasus-kasus dalam melakasanakan perataan laba, sudah menjadi informasi yang kita terima sehari-hari. Padahal perbuatan yang demikian akan mendapat ancaman dan peringatan Nabi shallallahu 'alaihi wa sallam. Dari Ma'qil bin Yasar al Muzani radhiyallahu 'anhu, ia berkata, "Aku mendengar Rasulullah shallallahu 'alaihi wa sallam bersabda:

$$
\text { ما من عبد يسترعيه الله رعية يموت يوم يموت وهو غاش لرعيته إلا حرم الله عليه الجنة }
$$

"Tidaklah seorang hamba yang Allah berikan kepemimpinan atas orang lain, lalu ia mati dalam keadaan berbuat curang terhadap orang-orang yang dipimpinnya, melainkan Allah akan mengharamkan atasnya surga.” (HR Muslim)

Walau pun hanya sedikit, harta yang didapatkan dengan jalan berbohong, menyembunyikan kecacatan, atau mengurangi timbangan adalah harta yang haram. Sudah seharusnya kita menjauhkan diri kita dari harta-harta semacam itu. Dikisahkan pada suatu hari Nabi shallallahu 'alaihi wa sallam berangkat bersama rombongan para sahabat ke pasar untuk melakukan pengecekan barang-barang dagangan. Saat itu beliau melewati gundukan makanan, kemudian beliau memasukkan tangannya dan mendapati bagian dalam dari gundukan itu basah. Beliau berkata, "Apa ini wahai penjual makanan?" la berkata, "Bagian ini terkena air hujan wahai Rasulullah.” beliau bersabda, 


$$
\text { أفلا جعلته فوق الطعام حتى يراه الناس! من غثنا فليس منا }
$$

“Mengapa engkau tidak meletakkannya di bagian atas, agar orang yang akan membeli dapat melihatnya? Barangsiapa yang berbuat curang kepada kami, maka ia bukan bagian dari golongan kami.” (HR Muslim)

Di sisi lain dalam aturan pelaporan keuangan diperbolehkan melakukan perataan laba akan tetapi padangan agama memiliki sudut padang yang berbeda dalam menjalankan syariat islam, padangan islam setiap prilaku kehidupan berdasar pada Alquran dan sunah, bahkan ada yang menjadikan ungkapan sebagai landasan untuk melegalkan dan menghalalkan segala cara demi mewujudkan niat baiknya, baik dalam urusan dunia maupun agama. Dalam era informasi saat ini, mudah sekali orang percaya dan menyebar-nyebarkan kabar berita yang tidak jelas asal dan sumbernya dari mana. Lebih parah lagi dengan adanya tehnologi informasi, sebagian orang acap kali membroadcast kabar berita yang isinya sampah, hoax dan menyesatkan. Terkadang isinya tidak saja kabar yang belum tentu kebenaranya, tapi juga hadist-hadist lemah (dha'if) dan palsu (maudhu') banyak disebar dan malah edit, dibuat-buat untuk menakut-nakuti. AlQur'an memberi petunjuk bahwa berita yang perlu diperhatikan dan diselidiki adalah berita yang sifatnya penting. Adapun isu-isu ringan, omong kosong, dan berita yang tidak bermanfaat tidak perlu diselidiki, bahkan tidak perlu didengarkan karena hanya akan menyita waktu dan energi.

Manajer berusaha memberikan informasi yang akan meningkatkan nilai perusahaan dimata investor yaitu dengan cara melakukan perataan laba (income smoothing). Tindakan manajemen untuk melakukan perataan laba umumnya didasarkan atas berbagai alasan. Antara lain untuk memuaskan kepentingan pemilik perusahaan, seperti menaikkan nilai dari perusahaan, sehingga muncul anggapan bahwa perusahaan yang bersangkutan memiliki risiko yang rendah. Jika investor semakin pintar dan punya akses terhadap informasi, akhirnya situasi yang sebenarnya akan terungkap juga dan keputusan yang dibuat akan berbeda, sehingga investor terhindar dari kerugian yang tak diinginkan. Perihal terjadinya tindakan perataan laba dapat dianalogikan bahwa pelaporan laporan keuangan melakukan tindakan tersebut agar laporan keuangan terlihat smooth (lembut), tidak fluktuatif sehingga akan membuat investor tertarik berinvestasi pada perusahaan tersebut. 


\section{SIMPULAN}

Dalam pandangan Islam, prilaku perataan laba ini sepertinya bertentangan dengan kaidah figh muamalah, dimana mengandung unsur penipuan (tadlis) dan ketidakjelasan (gharar) karena ada pihak yang menyembunyikan informasi terhadap pihak yang lain (unknown to one party) dengan maksud untuk menipu pihak lain atas ketidaktahuannya tentang informasi tersebut. Dan apabila tindakan ini terbukti, maka hal ini dilarang dalam Islam, karena melanggar prinsip “an taraaddin minkum” (samasama ridha). Tadlis terjadi karena adanya penyembunyian (cacat) atas informasi yang tidak diketahui oleh salah satu pihak yang bertransaksi. Yang dilarang disini bukanlah menjual barang cacatnya, tetapi adalah menyembunyikan cacatnya barang tersebut, sehingga informasi yang dimiliki para pihak tidak simetris (asymmetric information). Karena itu pula harus disaring, khawatir jangan sampai seorang melangkah tidak jelas atau dalam bahasa ayat ini bi jahalah. Dengan kata lain ayat ini menuntut kita menjadikan langkah kita berdasarkan pengetahuan sebagai lawan dari jahalah yang berarti kebodohan, disamping melakukannya berdasarkan pertimbangan logis dan nilai-nilai yang ditetapkan Allah SWT.

Islam juga tidak memisahkan agama dengan negara dan materi dengan spiritual sebagaimana yang dilakukan bangsa barat dengan sekularismenya. Islam juga berbeda dengan konsep kapitalisme yang memisahkan akhlak dengan ekonomi. Ekonomi dalam pandangan Islam bukanlah tujuan akhir dari kehidupan ini tetapi suatu pelengkap kehidupan, sarana untuk mencapai tujuan yang lebih tinggi, penunjang dan pelayanan bagi akidah dan bagi misi yang diembannya, Prinsip dasar yang telah ditetapkan dalam Islam mengenai usaha manusia dalam bermuamalah adalah tolok ukur dari kejujuran, kepercayaan dan ketulusan.

Pembatasan permasalahan dalam penelitian ini agar dapat mengidentifikas seluruh persoalan dan masalah perataan laba (income Smoothing) lebih jelas, maka peneliti membatasi analisis ini hanya pada pendapat persepsi informan tentang perataan laba (income smoothing) yang sering kali dilakukan oleh perusahaan dalam menjalankan usaha yang dilihat dari sudut pandang Agama Islam. 


\section{PUSTAKA ACUAN}

Adnan, M. Akhyar. 2005. Akuntansi Syariah; Arah, Prosfek dan Tantangan. Yogyakarta: UII Press.

Arlene. 2005. Persepsi Mahasiswa Akuntansi Terhadap Pearataan Laba. Tesis Tidak Dipublikasikan. Depok: Universitas Indonesia.

Baridwan, Z. 1996. Intermediate Accounting. Edisi 7. Yogyakarta : BPFE.

Beattie, V. S. Brown. D. Ewers. 1994. Extraordinary Items and Income Smooting; A Positive Accounting Appoach. Jurnal Bussiness Finance \& Acounting Research.

Beekun, Rafik. I. 1997. Islamic Bussiness Ethics. Virginia: International Institude of Islamic Thought.

Belkaoui, Achmad. 2000. Teori Akuntansi. Jilid 2. Jakarta : Salemba Empat.

Chancera, Dhiba. M. 20II. Pengaruh Manjaemen Laba Terhadap Biaya Modal Ekuitas pada Perusahaan Manufaktur yang Terdaftar di Bursa Efek Indonesia Tahun 2008-2009. Tesis Tidak Dipublikasikan. Semarang: Universitas Diponegoro.

Fischer, Marilyn dan Kenneth Rosenzweig. 1995. Attitudes of Students and Accounting Practitioners Concerning the Ethical Acceptability of Income Smoothing”. Journal of Bussines Ethics.

Ghozali, Imam. 2005. Aplikasi Analisis Multivariate Dengan Program SPSS. Semarang : BPFE Universitas Diponegoro.

Hendikson, E. 1999. Accounting Theory. Fith Edittion. Illinois : Richard D. Irwin, Inc.

Heyworth, S.R . 1953. Smoothing Periodic Income. The Accounting Review, Vol.I.

Husnan, Suad. 2003. Pembelanjaan Perusahaan (Dasar-Dasar Manajemen Keuangan). Yogyakarta Liberty.

Indiantoro, N. dan S. Bambang. 1999. Metodelogi Penelitian. Yogyakarta : BPFE.

Jatiningrum. 2000. Analisis Faktor-faktor yang Berpengaruh Terhadap Perataan Penghasilan Bersih/Laba pada Perusahaan yang Terdaftar di BEJ. Jurnal Bisnis dan Akuntansi, Vol. 2, No. 2 : |45-155.

Jin, Liauw She dan M. Machfoedz. 1998. Faktor-Faktor Yang Mempengaruhi Praktek Perataan Laba Pada Perusahaan Yang Terdaftar di Bursa Efek. Jurnal Riset Akuntansi Indonesia, Vol. I No. 2 
Jumingan. 2003. Faktor-Faktor yang Mempengaruhi Perataan Laba: Studi Empirik Pada Perusahaan Industri Farmasi di Bursa Efek Jakarta. Jurnal Akuntansi dan Investasi, Vol. 5.

Juniarti dan Corolina. 2005. Analisa Faktor-Faktor Yang Berpengaruh Terhadap Perataan Laba (Income Smooting) Pada Perusahaan-Perusahaan Go Public. Fakultas Ekonomi Petra : www.petra.ac.id. Diakses tanggal 19 Januari $201 \mathrm{I}$.

Merchant, K. A., dan J. Rockness. 1994. The Ethics of Managing Earnings; An Emprical Investigation. Journal of Public Policy; 79-94.

Michelson, E. Stuart et al. 1999. Income Smoothing and Risk Adjusted Performance. Working Paper Collection SSRN.

Murtanto. 2004. Analisis Perataan Laba :Faktor-Faktor Yang Mempengaruhi Dan Kaitannya Dengan Kinerja Saham Perusahaan Publik di Indonesia. SNA VII Denpasar.

Narjono, Arijo. Isnoer. 2013. Etika Islam dan Motivasi Kerja (Islam Ethics and Employee Motivation). Jurnal JIBEKA, Volume 7. Malang.

Nasser, E.M. dan Herlina. 2003. "Pengaruh Size, Profitabilitas dan leverage terhadap perataan Laba pada Perusahaan go Publik.” Jurnal Ekonomi, vol.7 (3), hal.29l 305.

Purwanto, Agus. 2004. Analisis Antara Praktik Perataan Laba Dengan Koefisien Respon Laba. SNA VII Denpasar.

Rahmawati, Suparno, Y., dan Qomariyah, N. 2006. Pengaruh Asimetri Informasi Terhadap Praktik Pearataan Laba pada Perusahaan Perbankan Publik yang Terdaftar di Bursa Efek Jakarta.

Rais, Sasli. 2002. PSAK No. 59;Pekerjaan yang Belum Selesai. Makalah Mata Kuliah Akuntansi Syariah. PSKTTI UI.

Riduwan, Akhmad. 2010. Etika dan Perilaku Koruptif dalam Praktik Pearataan Laba: Studi hermeneutika. STIESIA Surabaya".

Riyanto, Bambang. 2002. Dasar-dasar Pembelanjaan Perusahaan. Edisi 4. Yogyakarta : BPFE.

Saidi. 2008. Faktor-Faktor Yang Mempengaruhi Struktur Modal Pada Perusahaan Manufaktur Go Public Di BEl Tahun 1997-2002. Jurnal Bisnis dan Ekonomi, Vol. II. No. I. 
Salno, Hanna Melani dan Zaki Baridwan. 2000. Analisis Perataan Penghasilan (Income Smooting):Faktor-Faktor Yang Mempengaruhi Dan Kaitannya Dengan Kinerja Saham Perusahaan Publik Di Indonesia. Jurnal Riset Akuntansi Indonesia, Vol. 3 No. I.

Schipper, K. 1989. Commentary On Earnings Management. Accounting Horizon (3).

Scott, W.R. 2003. Financial Accounting Theory. New Jersey : Petience Hall International, Inc.

Suwito, Edy dan Herawaty Arleen. 2005. Analisis Pengaruh Karakteristik Perusahaan Terhadap Tindakan Perataan Laba Yang Dilakukan Oleh Perusahaan Yang Terdaftar di Bursa Efek Jakarta SNA VII Solo.

Syaharuddin, Hamam. 2012. Etika Bisnis Menurut Al-Qur'an dan Hadits. http://humamsyaharuddin.blogspot.co.id/2012/09/etika-bisnis-menurut-al-qurandan-hadits.html diakses tanggal I Januari 2016.

Umar, Husein. 1997. Metode Penelitian, Aplikasi dalam Pemasaran. Jakarta : Penerbit Gramedia.

Undang-Undang Republik Indonesia Nomor 28. 2007. Perubahan Ketiga Atas UndangUndang Nomor 6 Tahun 1983 Tentang Ketentuan Umum dan Tata Cara Perpajakan". Jakarta.

Virginia, Susana. 2014. Pentingnya Etika dalam Kehidupan Bermasyarakat. STP Nusa Dua Bali.

Williams, Chuck. 200I. Manajemen. Jakarta: Penerbit Salemba Empat.

Yin, Robert, K. 2002. Studi Kasus (Desain dan Metode). Jakarta: PT Raja Grafindo Persada. 